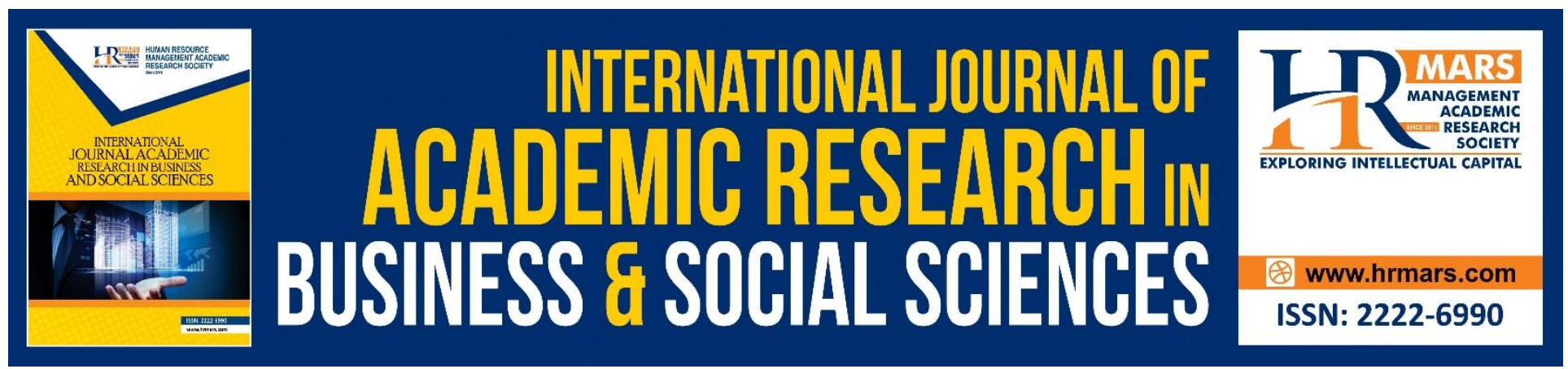

\title{
Assessment of Quality of Life on Fishermen Community in Kuala Terengganu, Malaysia: A Review
}

\section{Rezahan MOHD ZAIN, Mohd Khairul Amri KAMARUDIN, Muhammad Hafiz MD SAAD}

To Link this Article: http://dx.doi.org/10.6007/IJARBSS/v8-i10/4770

DOI: $10.6007 /$ IJARBSS/v8-i10/4770

Received: 11 Sept 2018, Revised: 18 Oct 2018, Accepted: 24 Oct 2018

Published Online: 29 October 2018

In-Text Citation: (Zain, Kamarudin, \& Saad, 2018)

To Cite this Article: Zain, R. M., Kamarudin, M. K. A., \& Saad, M. H. M. (2018). Assessment Of Quality Of Life On Fishermen Community In Kuala Terengganu, Malaysia: A Review. International Journal Of Academic Research In Business And Social Sciences, 8(10), 640-650.

\section{Copyright: (C) 2018 The Author(s)}

Published by Human Resource Management Academic Research Society (www.hrmars.com)

This article is published under the Creative Commons Attribution (CC BY 4.0) license. Anyone may reproduce, distribute, translate and create derivative works of this article (for both commercial and non-commercial purposes), subject to full attribution to the original publication and authors. The full terms of this license may be seen

at: http://creativecommons.org/licences/by/4.0/legalcode

Vol. 8, No. 10, 2018, Pg. 640 - 650

Full Terms \& Conditions of access and use can be found at http://hrmars.com/index.php/pages/detail/publication-ethics 


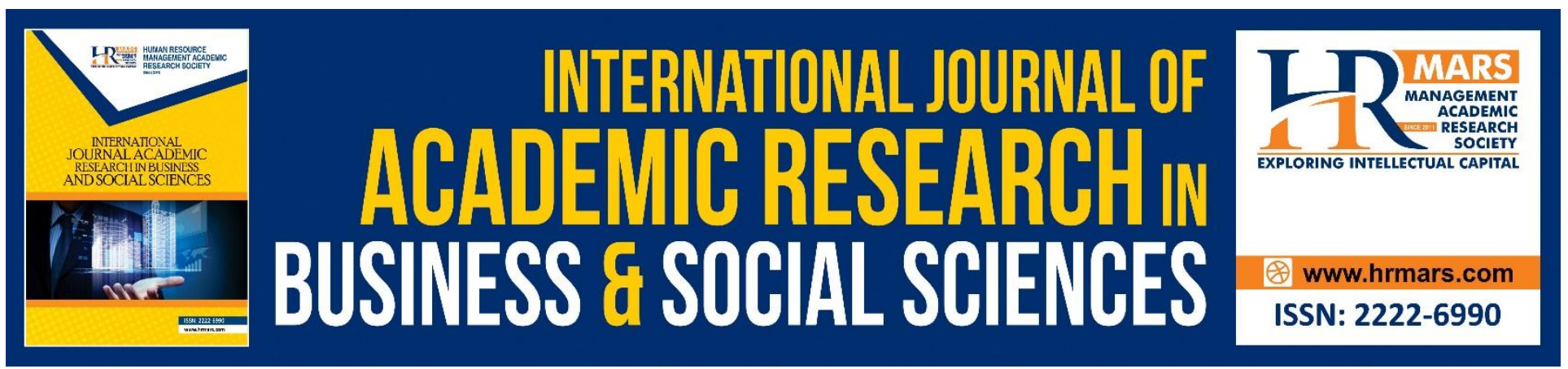

\title{
Assessment of Quality of Life on Fishermen Community in Kuala Terengganu, Malaysia: A Review
}

\author{
${ }^{1}$ Rezahan MOHD ZAIN, ${ }^{* 1,2}$ Mohd Khairul Amri KAMARUDIN, \\ ${ }^{1}$ Muhammad Hafiz MD SAAD \\ ${ }^{1}$ Faculty of Applied Social Science, Univerasiti Sultan Zainal Abidin, Kampus Gong Badak, 21300 \\ Terengganu, Malaysia \\ ${ }^{2}$ East Coast Environmental Institute (ESERI), Universiti Sultan Zainal Abidin, Kampus Gong Badak, \\ 21300 Terengganu, Malaysia. \\ Email: mkhairulamri@unisza.edu.my (Corresponding Author)
}

\begin{abstract}
This study discusses about the level of quality of fishermen living in Kuala Terengganu, Malaysia. The issue of quality of life of fishermen in Kuala Terengganu is very important to improve the average of quality of life in overall Kuala Terengganu. It is because; more natives people in Kuala Terengganu are came from Fishermen Community. In Terengganu, fishermen generally are divided into two types; it is coastal fishermen and deep-sea fishermen. The aim of this study is to review and identify the quality of life of the fishermen community either coastal fishermen or deep-sea fishermen. The results showed that the quality of life of fisherman's was at a moderate level. Nevertheless, the involvement of parties involved in particular the stakeholders in improving the standard of living of fishermen is very important to achieve a higher level of income, and also for quality of life of fishermen in Kuala Terengganu, Malaysia.
\end{abstract}

Keywords: Deep Sea Fishermen, Coastal Fishermen, Quality Of Life, Living Standards, Fishermen Community

\section{Introduction}

Fishermen refers to individuals who are looking for income to earn a living by catching fish or marine life such as shrimp or sea weed. Currently, in Terengganu Malaysia, fishermen's job is not only dominated by villagers, but urban dwellers living in coastal areas begin to venture into this area (Kamaruddin et al., 2015; Kamarudin et al., 2017; Portal Rasmi Jabatan Perikanan Malaysia, 2018). This has created various categories of fishermen that differentiate existing of fishermen. According to Mangi \& Roberts, (2007) the deep-sea fisheries are occurring at a depth of more than 30 nautical miles from the coast. The types of fishing gear and vessels that used in deep-sea fisheries are very greatly and it depends on the species and behavior marines that they targeted. Roger \& Lasse (2008) 
say that normally, this fishery is run under 200 meters on a continental slope or an isolated sea topographic structure such as seamount. So they have to use properly vessels that can carry them to the targeted places. Meanwhile, the coastal fisherman is form of local fisherman. They are older person which is age above 45 years old. They still use traditional methods to catch the fish like nets or drift nets. This is because they are not disclosed about how to fishing with the right or modern way. They also came from poor family. So they have to use an old ways and the number of catches is less and enough just for daily use.

According to Ali (2007), 60 percent of the world's population has made fishery sources as their daily protein. Nevertheless, fishermen are often categorized among the poor, especially fishermen in Asia. The issue of poverty struck among fishermen is an issue that needs to be taken seriously. The fishermen cannot enjoy their life like other people because of the poverty that they have to face. This group sells their catch to fishers at low prices due to the prices offered by low-cost fishers. Due to no choice, the fishermen were forced to sell their catches at cheap prices. In general, October to Mac is monsoon season in Terengganu areas and East Coast of Peninsula Malaysia (Lun et. al, 2011; Toriman et al., 2013; Azid et al., 2015; Wahab et al., 2016; Saudi et al., 2017). During that time, mostly fishermen cannot go to the sea. Employment as fishermen is a weather-dependent job, if the weather is good they will go out looking for sustenance and if the weather is otherwise, their work will be stunted for several months until the end of the monsoon season. This generally makes fishermen work as jobs that depend on the weather and cause the quality of life to be low.

Previous studies has discussed about fisheries. One of them is Hatcher (2000) has conduct a study on the role of public funds in the process of direct subsidization arrangements such as fishing boats, shipbuilding subsidies and upgrading of existing fishing boats. The results of the study found that the funds were able to raise the level of wellbeing and fishery's quality of life. Meanwhile, Nguyen (2007) has also examined the level of farmers' satisfaction with the aquaculture activities carried out on 120 fish breeders in Selatan Vietnam. The result shows that the farmers are satisfied with fish breeding increases in parallel with the involvement of the government in providing various assistance to farmers. One of the funds provided to farmers is to provide a larger and deep. That means, the more assistance it provides, the more income the farmer can afford. Therefore, the level of impressions and quality of life can be improved. Table 1 shows the differences between Coastal Fishermen and Deep-sea Fishermen based on summarized from Portal Rasmi Jabatan Perikanan Malaysia, (2018). 
INTERNATIONAL JOURNAL OF ACADEMIC RESEARCH IN BUSINESS AND SOCIAL SCIENCES Vol. 8, No. 10, Oct. 2018, E-ISSN: 2222-6990 @ 2018 HRMARS

Table 1: Differences between Coastal Fishermen and Deep-sea Fishermen

\begin{tabular}{|c|c|c|}
\hline Scope & Coastal fisherman & Deep-sea fisherman \\
\hline Location & $\begin{array}{l}\text { On the coast, less than } 30 \\
\text { nautical miles from the coast } \\
\text { (Peninsular Malaysia, Sabah, } \\
\text { Sarawak) }\end{array}$ & $\begin{array}{l}\text { Deep Sea, Exclusive Economic Zone (ZEE) } \\
\text { area that exceeds } 30 \text { nautical miles from the } \\
\text { coast }\end{array}$ \\
\hline Time & $\begin{array}{l}\text { Half a day, early morning until } \\
\text { late afternoon }\end{array}$ & Weeks or months \\
\hline Scale & Small scale and catches & Large lot of catches \\
\hline $\begin{array}{l}\text { Haul } \\
\text { (Orientation) }\end{array}$ & $\begin{array}{l}\text { Daily sale on local market, family } \\
\text { use }\end{array}$ & For sale in local and overseas \\
\hline \multirow[t]{2}{*}{ Haul } & Fish coastline & Deep-sea fish \\
\hline & $\begin{array}{l}\text { Examples: kembong and } \\
\text { selayang }\end{array}$ & Examples: tuna, mackerel, calm \\
\hline Capital & $\begin{array}{l}\text { Small- own capital or a loan from } \\
\text { family }\end{array}$ & $\begin{array}{l}\text { Large capital - owned by large corporations } \\
\text { or large-scale fishermen associations, bank } \\
\text { loans }\end{array}$ \\
\hline Equipment / & Traditional & Modern \\
\hline Technology & $\begin{array}{l}\text { Example: drift nets, fishing rods, } \\
\text { nets }\end{array}$ & $\begin{array}{l}\text { Examples: powerful bots, ecosons (fish } \\
\text { detectors) }\end{array}$ \\
\hline Labor & $\begin{array}{l}\text { Little- family members, } \\
\text { neighbors } \\
\text { (Daily workers) }\end{array}$ & $\begin{array}{l}\text { Many- trained fisherman, imported skilled } \\
\text { laborers }\end{array}$ \\
\hline
\end{tabular}

(Source: Summarized from Portal Rasmi Jabatan Perikanan Malaysia, (2018)

Based on the table above, it tells us about differentiate between coastal fisherman and deep-sea fisherman. In large areas, coastal fishing will choose on the coastline of approximately 30 nautical miles from the coast (Peninsular Malaysia, Sabah and Sarawak), and the location of deep-sea fishermen are in the Exclusive Economic (EEZ) of more than 30 nautical miles from the edge beach. The scope of the time anyway, coastal fishermen only takes half day that is early morning to late afternoon compared to deep-sea fishermen who take a long time, specifically for weeks or months. In the scope of the scaling scale, coastal fishermen only involved small scales and catches were also minimal compared to deep-sea fishermen involving large scales and greater retention results.

In the scope of the capture scale, coastal fishermen are only involved in small scale and are also slightly smaller than in deep sea fishermen involving large scale and catchments. The catch for coastal 
fishermen will be used for daily use of the family and sold on a daily basis in the local market while proceeds for deep sea fishermen will be sold locally and abroad. The catches of coastal fishermen such as fish and mackerel while catching for deep sea fishermen such as tuna, mackerel and grouper. Fishing equipment for coastal fishermen are more traditional equipment such as drift nets, fishing tackle and net while equipment used by deeper sea fishermen is more modern like high-powered bots and eco-sonars.

In the capital's scope, the capital required by the coastal fishermen is small due to their own capital or loans from family members while the capital needed by deep-sea fishermen is more because of large-owned or fishery associations with large capital and lending from banks. The labor force used by the coastal fishermen is a bit of a family or a neighbor while for the sea fishermen in the labor force is required from trained fishermen and skilled labor import.

\section{Quality of Life}

Previous studies have discussed a lot about the quality of life. Among of them is, Costanza et al., (2007) says that the concept of quality of life by integrating it with opportunities, human needs and well-being. According to him, the concept of quality of life refers to the extent that human needs are met and they are measured objectively and subjective. Human needs refer to basic needs for life, such as safety, self-sufficiency and reproductive. In addition, the quality of life is seen from various aspects including discipline, medicine, discipline, sociology, economics and environmental science fulfilling the basic human needs of psychology, economic, physical and social biology (Bubolz et al., 1980; Goldsmith, 2005; Costanza et al., 2007; Ali et al., 2017). Smith \& Clay (2010) say that the quality of life is a common concept in behavior, anthropology, economics, psychology, sociology and other social sciences. Meanwhile, according to Laily \& Jariah (2003), a previous study has been made on the quality of family life on financial resources and the use of such resources in achieves the required goals. There are several variables that can be used to measure prosperity and quality of life. They are expenditure, income, poverty line, income, property, consumer price index, socioeconomic status, education and employment (Laily \& Lokman, 2005). In addition, well-being and quality of life can also be seen by focusing on important aspects such as health, family life and housing (Laily et al., 1999). Besides, well-being is a stress-free feeling, joyfully overcoming sad feelings over a long period of time, feeling positive and achieving what is desired alongside goals. The quality of life in the fishing community should be given due attention because the average fishing community, especially the coastal fishing community, is among the poor (Pollnac et al., 2001; Pollnac \& Poggie, 2008; Mohd Shaladdin et al., 2006) except for fishermen in Kuala Terengganu, Terengganu, Malaysia.

\section{Literature Review}

This study needs a high understanding of the quality of life between coastal fishermen and deep-sea fishermen. This study is a reviews study, so early research will be conducted by referring previous studies of journals, books, and other scientific materials. Among the examples of previous studies that have been taken are conducted by Zaimah et al., (2015) on subjective wellbeing: A study in Sedili, Kota Tinggi, Johore, Malaysia. A total of 200 respondents were interviewed using the questionnaire. This method is particularly suitable to be used to measure the level of well-being and quality of life of fishermen. Respondents are fishermen in Sedili, Johor. The results showed that the level of 
wellbeing and quality of fishermen in Sedili was at a high level, both coastal fishermen and deep-sea fishermen. Nevertheless, the involvement of the government in improving fishermen's life is crucial to achieving higher levels of income for the wellbeing and quality of life to be enjoyed.

In addition, another study on fishermen was also made by Mohd Shaladdin et al., (2006). The study is the Analysis of Coastal Fishery Wellbeing. This study focus on four main aspects of fisherman's profile or attributes, government role, community role and demographic. The research method used in this study is a questionnaire. A total of 120 sets of questionnaires were randomly distributed not only to fishermen but also distributed around Kuala Terengganu. The results showed that there are still many fishermen who have a problem and belongs to the category of rural poor. Government roles are needed in line with efforts to improve the living standards of fishermen in Malaysia. If the two sides of the government and fishermen are effective, the fishermen's well-being will be improved. Next, Jalihah et al., (2014) conducted a study on the categorization of urban fishermen and poverty: Research on fishermen in Gaya Island, Kota Kinabalu, Sabah, Malaysia. The fishery category is based on the finances of poor and poorest monetary terms while the non-monetary category refers to the level of fishermen involvement in fish penetration activities whether full or part-time and technology used. The method used in this study also used the interview method and 45 respondents were interviewed. The majority of fishermen here do not have a high school education since childhood. Therefore, teenagers here spend their time with fishermen to help their parents. The study found that the level of the community, the use of non-financial indicators were widespread and dominant in determining the categories of fishing which exist in Kampung Pulau Gaya, Malaysia.

On the quality of life, a study was conducted by Ummi Munirah Syuhada et al., (2016) on the Wellbeing Indoor Community Index: A study among IPTA students. The study uses a number of components found in both indices, the Malaysian Quality of Life Index (IKHM) further expanded to the Malaysian Wellbeing Index (IKRM). The method used in this study is the questionnaire. A total of eight public universities are involved in clusters set by the Ministry of Higher Education Malaysia (KPT). The total number of respondents is 894 students. The findings of the study found that the IPTA students' well-being index was at moderate level. In addition, another study was made by Hayrol Azril et al., (2013). This study is about the process of social adaptation towards climate change among Malaysian fishermen. The method that used in this study is questionnaire. These forms were given to 75 respondents for Kelantan, Terengganu, Pahang and Johor. The findings show that most of the fishermen are only educated in primary schools only. They are also not exposed to advances in fishing like fishing technology and so on. When the monsoon season, they cannot go down to the sea to catch fish. Therefore they are forced to do other work or do not work. Their salaries also very low, of course, their quality of life is also low even though fishermen are one of the most beneficial nations in terms of fishing

Along with the study, there is another study on the quality and well-being of fishermen's life. This study was conducted by Edwin et al., (2018). This study is about Need Analysis of Coastal Fisherman Empowerment Based on Economics education and Potential Coastal in Minahasa Regency of North 
Sulawesi. The method for this study is interview method, observation and focus group discussion. About 40 respondents consisted of coastal fishermen in Minahasa. They were asked about their work and the cost of living that they should bear every month. The average fisherman is merely a fisherman and not knowledgeable in business or fishery. They also do not know about the current type of equipment that is suitable for large quantities of fishing, although only on the coast. The absence of other knowledge and skills to advance itself will cause the fishermen to survive in disadvantages.

\section{Discussions}

Based on this study, among the major factors that cause fisherman's quality of life to be low is due to educational factors (Laily \& Lokman, 2005). The lack of education is one of the reasons for fisherman quality to be low supported (Sudarso, 2008). Through its study titled Structural Poverty Stress states that fishermen, in particular, traditional fishermen, generally have the same characteristic of being uneducated. The main factor of society is not continuing education because of family economic factors. In addition, parents are forced to harness the power of their children to help increase family income and reduce family burden. With their educational background low, it will inconvenience them to get a better job.

Attitudes do not want to change lives is one of the factors of the quality of life of fishermen to be low. Fishermen's children will continue to inherit jobs from their families for life, even though the income they earn will be less. According to Goodwin (1991) in his study entitled Crisis in the World's Fisheries: People Problem and Policies states that fishermen will pass the tradition of fishing to the next generation although the work is marginally. Therefore, a study from Kusdiantoro (2005) titled Pilpres and Fisherman's Fate says that one action needs to be done to address poverty among fishermen by altering the behavior of the fishermen community itself. It is supported by Nieboer et al. (2005) says that achievement of goals, behaviors, status and comfort is an indicator of the wellbeing of life. In his study, he used the structural equation modeling to test the model that had been formed. Therefore, fishermen need to change their way of life with certain skills so that their lives will not depend only on fishermen's work.

In addition, the factors that drive the fishermen's quality of life are the competition between the fishermen themselves. Moreover, the coastal fishermen in whom the fishing area is limited, hence competition occurs. Kusnadi (2002) argues that limited fish and area sources create competition between small fishermen in the coast. The fishermen will fight the area and the catch to earn lucrative income without thinking of other fishermen. According to Ardiyanto \& Ida, (2017), his study about characteristics and poverty level of people in Sukolilo fisherman village Surabaya, Indonesia based on sustainable livelihood approach, his said that there was an unhealthy competition between fishermen. This information was obtained from the interviews of several fishermen. The dispute is not shown openly but in reality this factor will reverse the fishermen's own society. This will also lower the fishermen's quality of life. 


\section{Conclusion}

Fishermen are the job of catching seas to support himself and his family life. In Terengganu, Malaysia, fishermen generally are divided into two: coastal fishermen and deep-sea fishermen. Among the factors that cause the quality of life of the fishermen to be low due to educational factors. Some fishermen's children do not go to school and just follow their parents go to the sea to catch fish. Poor fishermen cannot afford the school fees of their children led out of school and illiteracy rates increase. Therefore, some appropriate proposals to solve the problem are: The government should provide financial assistance and clothing to the fishermen so that their children can go to school and get a better job in the future. Besides charging low fees to children of fishermen who go to school and food assistance each morning. This also improves the quality of life of fishermen community.

The next factor that led to the resignation of the quality of life of fishermen does not want to change the attitude. This can be attributed to fishing gear. They are more comfortable using traditional equipment even though the catch is not much. Therefore, they need more assistance. The stakeholders should provide some maintenance such as oil subsidies and more sophisticated fishing equipment assistance to capture more. In addition, parts of boats obtained for free or at cheap prices. In addition, emotional support should also be provided so that they gain confidence to change their lives and replace traditional to modern equipment. This ensures the quality of life of fishermen community.

The last factor that causes low fisherman's quality of life is due to the competition between the fishermen themselves. For a lot of profit, the fishermen are willing to compete with them. They are able to steal or deceive and invade fishing fishermen. Therefore, in order to solve this problem, the stakeholders should play a role by setting fishing areas where fishermen outside the area cannot enter to steal the fish. The enforcement of marine law should be more aggressive. With this assistance, the catch of fishermen will be much better and will be increase the quality of life of fishermen's in Terengganu, Malaysia.

\section{Acknowledgement}

The authors acknowledge the Ministry of Higher Education Malaysia (MOHE) for Scholarship under Research Grants: FRGS/1/2017/WAB05/UNISZA/01/1-RR222. Special thanks are also dedicated to East Cost Environmental Research Institute (ESERI) for the support, advice, guidance for this study.

\section{Corresponding Author}

Mohd Khairul Amri KAMARUDIN, Email: mkhairulamri@unisza.edu.my

\section{References}

Ali N. A. M, Mohamad, M., Juahir, H., Kamarudin, M. K. A, Muhammad, N., Lee, M. S. M. R. (2017). Source apportionment of social support and quality of life index among drug abuse inmates using multiple linear regressions. Journal of Fundamental and Applied Sciences, 9(2S), 46-65.

Ali, I. (2007). Pembangunan Industri Hiliran Berasaskan Perikanan di Sabah. Penerbit Universiti Malaysia Sabah. pp. 226. ISBN: 9789832369684 
INTERNATIONAL JOURNAL OF ACADEMIC RESEARCH IN BUSINESS AND SOCIAL SCIENCES

Vol. 8, No. 10, Oct. 2018, E-ISSN: 2222-6990 @ 2018 HRMARS

Ardiyanto, M. G. \& Ida, S. (2017). The Characteristics and Poverty Level of People in Sukolilo Fisherman Village Surabaya Based on Sustainable Livelihood Approach. Journal of Economics and Sustainable Development, 8(20): 18-22. ISSN 2222-1700

Azid, A., Juahir, H., Ezani, E., Toriman, M. E., Endut, A., Rahman, M. N. A., ... \& Umar, R. (2015). Identification Source of Variation on Regional Impact of Air Quality Pattern Using Chemometric. Aerosol and Air Quality Research, 15: 1545-1558.

Bubolz M. M., Eicher J. B., Evers S. J., Sontag M. S. (1980) A human ecological approach to quality of life: Conceptual framework and results of a preliminary study. Social Indicator Research, 7: 103- 136.

Costanza R., Fisher B., Ali S. (2007) Quality of life: An approach integrating opportunities, human needs, and subjective well-being. Ecological Economics, 61: 267-276.

Edwin W., Ery Tri D., Mit W., Hari W. (2018). Need Analysis of Coastal Fisherman empowerment Based on Economics education and Potential Coastal in Minahasa Regency of North Sulawesi. IOP Conference Series Earth and Environmental Science, 156(1):012026 DOI: 10.1088/17551315/156/1/012026

Goldsmith, E. B. (2005) Resource management for individuals and families, 3rd edition. Thompson Wadsworth, United States. ISBN-13: 978-0132955140

Goodwin, J. R. (1991). Crisis in the World's Fisheris: People Problem and Policies. California: Standford University Press. pp.248. ISBN: 9780804798723

Hatcher, A. (2000). Subsidies for European fishing fleets: the European Community's structural policy for fisheries 1971-1999, Marine Policy, 24(2): 129-140.

Hayrol Azril, M. S., Bahaman, A. S., Jeffrey, L. D., Sulaiman, M. Y. (2013). The process of social adaptation towards climate change among Malaysian fishermen. International Journal of Climate Change Strategies and Management, 5(1): 38-53.

Jalihah, M. D., Shah, Hafizah, S. (2014). Pengkategorian Nelayan Bandar dan Kemiskinan: Penelitian Terhadap Nelayan di Pulau Gaya, Kota Kinabalu, Sabah. https://www.academia.edu/35262796/pengkategorian nelayan Jurnal Kinabalu .pdf [Access on 25/09/2018].

Kamaruddin, A. F., Toriman, M. E., Juahir, H., Zain, S. M., Rahman, M. N. A., Kamarudin, M. K. A., \& Azid, A. (2015). Spatial characterization and identification sources of pollution using multivariate analysis at Terengganu river basin, Malaysia. Jurnal Teknologi, 77(1), 269-273.

Kamarudin, M. K. A., Nalado, A. M., Kasmuri, A., Toriman, M. E., Juahir, H., Umar, R., ... \& Hassan, A. R. (2017). Assessment of river plan changes in Terengganu River using RS and GIS method. Journal of Fundamental and Applied Sciences, 9(2S), 28-45.

Kusdiantoro. (2005). Pilpres dan Nasib Nelayan, http://www.pikiran-rakyat.com/cetak/0804/30/ teropong/lainnya1.htm [Access on [21/12/2005] in Anas Tain (2013). Faktor Dominan Penyebab Kemiskinan Rumah Tangga Nelayan Motor Tempel Di Wilayah Tangkap Lebih Jawa Timur. Sosiohumaniora, 15(1): 35 - 44.

Kusnadi. (2002). Konflik Sosial Nelayan Kemiskinan dan Perebutan Sumber Daya Perikanan, Yogyakarta: LKiS. pp. 190. ISBN: 9799492688 
INTERNATIONAL JOURNAL OF ACADEMIC RESEARCH IN BUSINESS AND SOCIAL SCIENCES

Vol. 8, No. 10, Oct. 2018, E-ISSN: 2222-6990 @ 2018 HRMARS

Laily P., Ahmad H. H., Nurizan Y. (1999) Kesejahteraan hidup di kalangan isi rumah perumahan kos rendah di bandar metropolitan. Malaysian Journal of Consumer and Family Economics, 2, 2336.

Laily P., Jariah M. (2003) Pengenalan ekonomi pengguna. Penerbit UPM, Serdang, Malaysia.

Laily P., Lokman I. (2005) Perbelanjaan pengangkutan dan komunikasi di kalangan pengguna di Batu Pahat, Johor. Malaysian Journal of Consumer and Family Economics, 8: 101-113.

Lun, P. I., Gasim, M. B., Toriman, M. E., Rahim, S. A., \& Kamaruddin, K. A. (2011). Hydrological Pattern Of Pahang River Basin And Their Relation To Flood Historical Event. e-BANGI, 6(1), 9.

Mangi, S. C. \& Roberts, C. M. (2007). Factor influencing fish catch levels on Kenya's coral reefs. Fisheries Management and Ecology, 14(4): 245-253.

Mohd Shaladdin M., Wan Abdul Aziz W. M. A., Nik Wan O. (2006) Analisis kesejahteraan hidup nelayan pesisir. Jurnal Kemanusiaan, 4(2): 58-77.

Nguyen M. D. (2007) Farmer's satisfaction with aquaculture - A logistic model in Vietnam. Journal of Ecological Economics 68, S25-S31.

Nieboer, A., Lindenberg, S., Boomsma, A. Van Bruggen, A. C. (2005). Dimensions of well-being and their measurement: The spf-II scale, Sociallndicators Research, 73(3): 313-353.

Pollnac R. B, Poggie J. J. (2008) Happiness, well-being and psychocultural to the stresses associated with marine fishing. Human Ecology Review, 15(2): 194-200.

Pollnac, R. B, Pomeroy, R. S., Harkes, I. H.T. (2001). Fishery policy and job satisfaction in three Southeast Asian fisheries. Ocean and Coastal Management, 44: 531-544.

Portal Rasmi Jabatan Perikanan Malaysia. (2018). Kementerian Pertanian \& industry Asas Tani Malaysia. https://www.dof.gov.my/index.php/pages/view/42 [Access on 28/08/2018].

Roger B. L. \& Lasse R. (2008). Improved catch on cod (Gadus morhua), haddock (Melanogrammus aeglefinus) and Greenland halibut (Reinhardtius hippoglossoides) with a new hauling technique in the Norwegian mechanized bottom long line fishery. Fisheries Research, 94(2): $160-165$.

Saudi, A. S. M., Kamarudin, M. K. A., Ridzuan, I. S. D., Ishak, R., Azid, A., \& Rizman, Z. I. (2017). Flood risk index pattern assessment: Case study in Langat river basin. Journal of Fundamental and Applied Sciences, 9(2S), 12-27.

Smith, C. L. \& Clay, P. M. (2010). Measuring subjective and objective well-being: analyses from five marine commercial fisheries. Human Organization, 69(2): 158-168.

Sudarso (2008). Tekanan kemiskinan struktural komunitas nelayan tradisional di perkotaan. Masyarakat, Kebudayaan dan Politik, 20(2): 87-102. ISSN: 0216-2407

Toriman, M. E., Ata, F. M., Kamarudin, M. K. A., \& Idris, M. (2013). Bed-load sediment profile and effect of river bank erosion on river cross-section. American Journal of Environmental Sciences, 9(4), 292-300.

Ummi Munirah Syuhada, M. Z., Mansor, M. N., Wan Shahzlinda Shah, W. S. (2016). Kesejahteraan Hidup Dalam Masyarakat Kepelbagaian: Kajian Dalam Kalangan Pelajar IPTA. Proceeding of the 3rdinternational Conference on Management \& Muamalah 2016 (3rdICoMM) 31stOctober-1stNovember 2016, 978-967-0850-61-0299INDEKS.

Wahab, N. A., Kamarudin, M. K. A., Gasim, M. B., Umar, R., Ata, F. M., \& Sulaiman, N. H. (2016). Assessment of total suspended sediment and bed sediment grains in upstream areas of Lata 
INTERNATIONAL JOURNAL OF ACADEMIC RESEARCH IN BUSINESS AND SOCIAL SCIENCES

Vol. 8, No. 10, Oct. 2018, E-ISSN: 2222-6990 @ 2018 HRMARS

Berangin, Terengganu. International Journal on Advanced Science, Engineering and Information Technology, 6(5), 757-763.

Zaimah, R., Suhana, S., Azima, A. M., Mohd Yosuf, H., Mohd Shamsudin, M. O., Ishak, Y. (2015) on subjective wellbeing: A study in Sedili, Kota Tinggi, Johore. Malaysia Journal of Society and Space, 11(2): 87-94. 